\title{
Comparative Foliar Epidermal Studies in Coix lacryma-jobi L. and Coix aquatica Roxb. (Poaceae)
}

\author{
Rinku J.DESAI, Vinay M. RAOLE, Arun ARYA \\ The Maharaja Sayajirao University of Baroda, Faculty of Science, Department of Botany, Vadodara- \\ 390 002, India; vmraole@rediffmail.com (corresponding author)
}

\begin{abstract}
As micromorphological knowledge was not available for Coix aquatica Roxb., the foliar epidermal studies were carried out for Coix lacryma-jobi L. and Coix aquatica Roxb. with the aim of determining the patterns of variation in their epidermal characteristics and assessing their value in species identification. Comparative foliar analysis was carried out by using light microscopy, after following routine scraping method. The characters of diagnostic importance in the identification of $C$. aquatica are the sparsely distributed prickle hairs with long pointed apex in the abaxial epidermis and dumbbell shaped silica cells in both the epidermises. The diagnostic characters for $C$. lacryma-jobi are the cross shaped silica cells and dumbbell shaped on the abaxial and adaxial epidermis respectively. The observed differences in certain micromorphological characters helps in identification of presently studied two species of Coix.
\end{abstract}

Keywords: Coix, foliar epidermis, prickle hair, silica cells and angular prickles.

\section{Introduction}

The genus Coix belongs to the family Poaceae which comprises of about 900 genera and 10.000 species throughout the world (GPWG, 2001). Coix is a genus of about 5 species, native to tropical Asia (Clayton and Renvoize, 1999; Watson and Dallwitz, 1992 onwards); commonly known as Job's tears, Christ's tears, adlai, Kasai and Kahudo. It is halophytic to hydrophytic to mesophytic; growing along the margin of the water bodies. In India, 4 species are noticed in wild state and are often cultivated as a border to roads and paths. The utricles are used for decoration, medicine, as food, as flour or for the production of beer and ornaments. The leaves are also used as fodder and for thatching by tribal people (Jain and Benerjee, 1974).

The grass family Poaceae is known for its wide diversity and complexity and so has posed many problems to the taxonomists using the traditional methods, based on gross morphology and described the leaf epidermis as the second most important character after cytology for solving taxonomic problem (Srivastava, 1978). Of all the nonreproductive organs, the leaf is the most widely used plant organ in plant taxonomy (Stace, 1984). Following the works of Metcalfe (1960) which today serve as standard references to plant anatomy, the use of vegetative anatomical characters in taxonomy became a routine procedure. Since then, the immense value of the leaf epidermis and vegetative anatomy in grass systematics has been demonstrated by many workers (Srivastava, 1978; Renvoize, 1982; Ogundipe and Olatunji, 1991).

Perusal of literature suggests that there are no reports on micromorphology of Coix aquatica Roxb., Watson and
Dallwitz (1992 onwards) have described micromorphology of Coix lacryma-jobi L. only. Hence, in the present study we have described the patterns of variation in epidermal characteristics, to assess their value in species identification, classification and in establishing the taxonomic relationships between the two species of Coix.

\section{Materials and methods}

Both the species of Coix i.e. C. lacryma-jobi and $C$. aquatica were collected from the natural vegetation nearby Konark temple, Orissa and Vadodara district, Gujarat respectively from India. Details of the voucher specimens are deposited in BARO herbarium with Accession number RJD/64 and RJD/56 respectively (Department of Botany, Faculty of Science, The Maharaja Sayajirao University of Baroda, Vadodara-390002, Gujarat, India). For micromorphological study, the leaves from the middle of the culms $\left(3^{\text {rd }}\right.$ and $\left.5^{\text {th }}\right)$ were used throughout the preparation. The peels were made by scraping pieces of fresh or softened dried leaves (Glycerine: Water mixture) with the help of safety razor blade and stained it with the saffranin and phenol to be mounted in glycerine (Hilu and Randall, 1984). Adaxial and abaxial leaf surfaces from both the species were studied at $\times 400$ magnification and individual cells were identified and measured by micrometer. 20-25 peels were made from each species of several dozen of leaves. All the peels were examined and the representative areas were photographed using Leica research microscope using $\times 40$ objective. Final counts of different cells (average of 50 observations) summarized in the Tab. 1 and 2 . 
38

\section{Results and discussion}

The characteristic epidermal micromorphological features for both the taxa have been depicted in the Fig. 1 and numerical variation in Tab. 1 and 2 .

\section{Coix lacryma-jobi $\mathrm{L}$.}

Long cells: Rectangular; walls thick, sinuous; inter stomatal cells relatively longer with concave ends. Short cells: Present over and between the veins, paired with cork cell. Anticlinal walls: Straight. Stomata: Large, frequent, paracytic type, subsidiary cells triangular. Microhairs: Bicellular with rounded-dome shaped cap cell, cap cell much longer than the basal cell, 45-50 × 7-8 $\mu$, Width/Length
0.14. Silica bodies: Dumbbell shaped, alternate with short cell files of the costal zones and in 1-3 rows over veins, 21$25 \times 12-15 \mu$; Prickle hairs: With swollen rounded base and sharp pointed apex, over the veins, $30-45 \times 10-12 \mu$ (Fig. 1: f-j).

Metcalfe (1960) pointed out that most of the characters of the leaf epidermis such as shape of the subsidiary cells of the stomata, micro hairs, prickle hairs and silica bodies are important in systematics of the family Poaceae. Recently numerous researchers have given importance to plant micromorphological characters. Whang et al. (1998) has differentiated the 17 species of Oryza on the basis of leaf epidermal characters along with the silica cells. Acedo and Llamas (2001) has given the micromorphological charac-

Tab. 1. Descriptive statistics of leaf epidermal attributes of Coix aquatica Roxb.

\begin{tabular}{cccccc}
\hline Trait & $\begin{array}{c}\text { Minimum } \\
(\mu)\end{array}$ & Maximum $(\mu)$ & Mean $(\mu)$ & $\begin{array}{c}\text { Standard } \\
\text { Dev. }(\mu)\end{array}$ & $\begin{array}{c}\text { Standard } \\
\text { Error }(\mu)\end{array}$ \\
\hline Length of stomata & 45 & 51 & 48 & 1.73 & \pm 1.23 \\
Width of stomata & 18 & 21 & 19.5 & 1.22 & \pm 0.86 \\
Length of long cells & 120 & 150 & 135 & 3.87 & \pm 2.75 \\
Width of long cells & 12 & 15 & 13.5 & 1.22 & \pm 0.86 \\
Length of Interstomatal cell & 100 & 130 & 115 & 3.87 & \pm 2.75 \\
Width of Interstomatal cell & 12 & 15 & 13.5 & 1.22 & \pm 0.86 \\
Length of Prickle hair & 30 & 45 & 37.5 & 2.74 & \pm 1.94 \\
Width of Prickle hair & 12 & 15 & 13.5 & 1.22 & \pm 0.86 \\
\hline
\end{tabular}

ratio 0.16. Silica bodies: Cross shaped on abaxial epidermis and Dumbbell shaped on adaxial epidermis, alternate with short cell files of the costal zones and in 1-3 rows over veins, $21-25 \times 27-30 \mu$ (for cross shaped), $21-25 \times$ 12-15 $\mu$ (for Dumbbell shaped); Prickle hairs: With swollen rounded base and sharp pointed apex, over the veins, $25-40 \times 10-12 \mu$ (fig. 1 : a-e).

\section{Coix aquatica Roxb.}

Long cells: Rectangular; walls thick, sinuous; inter stomatal cells relatively longer with concave ends. Short cells: Present over the veins only, paired with cork cell. Anticlinal walls: Straight. Stomata: Large, frequent, paracytic type, subsidiary cells triangular. Microhairs: Bicellular with rounded-dome shaped cap cell, cap cell much longer than the basal cell, 60-70 $\times 8-10 \mu$, Width/Length ratio ters in Bromus for systematic relationship. Observations regarding the leaf epidermis of Coix are in accordance with the report of the Renvoize (1982), wherein general trend of leaf micromorphological and anatomical characters are described for the members of Andropogoneae at generic level. Micromorphological features of Coix lacryma-jobi has been described by the Watson and Dalwitz (1992 onwards). The leaf epidermal layers of $C$. aquatica and C. lacryma-jobi showed significant degrees of variations in terms of the micromorphological characters found in them. In both the species shape of silica cells, arrangement of the angular hairs and prickle hairs showed significant differences between $C$. aquatica and $C$. lacryma-jobi. The long cells found in the epidermis of $C$. aquatica were longer than $C$. lacryma-jobi. The long cells found in $C$. lacryma-jobi were 20-25 rowed on the abaxial and 4-10 rowed

Tab. 2. Descriptive statistics of leaf epidermal attributes of Coix lacryma-jobi L.

\begin{tabular}{|c|c|c|c|c|c|}
\hline Trait & $\operatorname{Minimum}(\mu)$ & $\operatorname{Maximum}(\mu)$ & $\operatorname{Mean}(\mu)$ & Standard Dev. $(\mu)$ & Standard Error $(\mu)$ \\
\hline Length of stomata & 45 & 51 & 48 & 1.73 & \pm 1.23 \\
\hline Width of stomata & 30 & 32 & 31 & 1.00 & \pm 0.71 \\
\hline Length of long cells & 90 & 135 & 112.5 & 4.74 & \pm 3.36 \\
\hline Width of long cells & 30 & 36 & 33 & 1.73 & \pm 1.23 \\
\hline Length of Interstomatal cell & 100 & 120 & 110 & 3.16 & \pm 2.24 \\
\hline Width of Interstomatal cell & 30 & 36 & 33 & 1.73 & \pm 1.23 \\
\hline Length of Prickle hair & 25 & 40 & 32.5 & 2.74 & \pm 1.94 \\
\hline Width of Prickle hair & 10 & 14 & 12 & 1.41 & \pm 1.00 \\
\hline
\end{tabular}



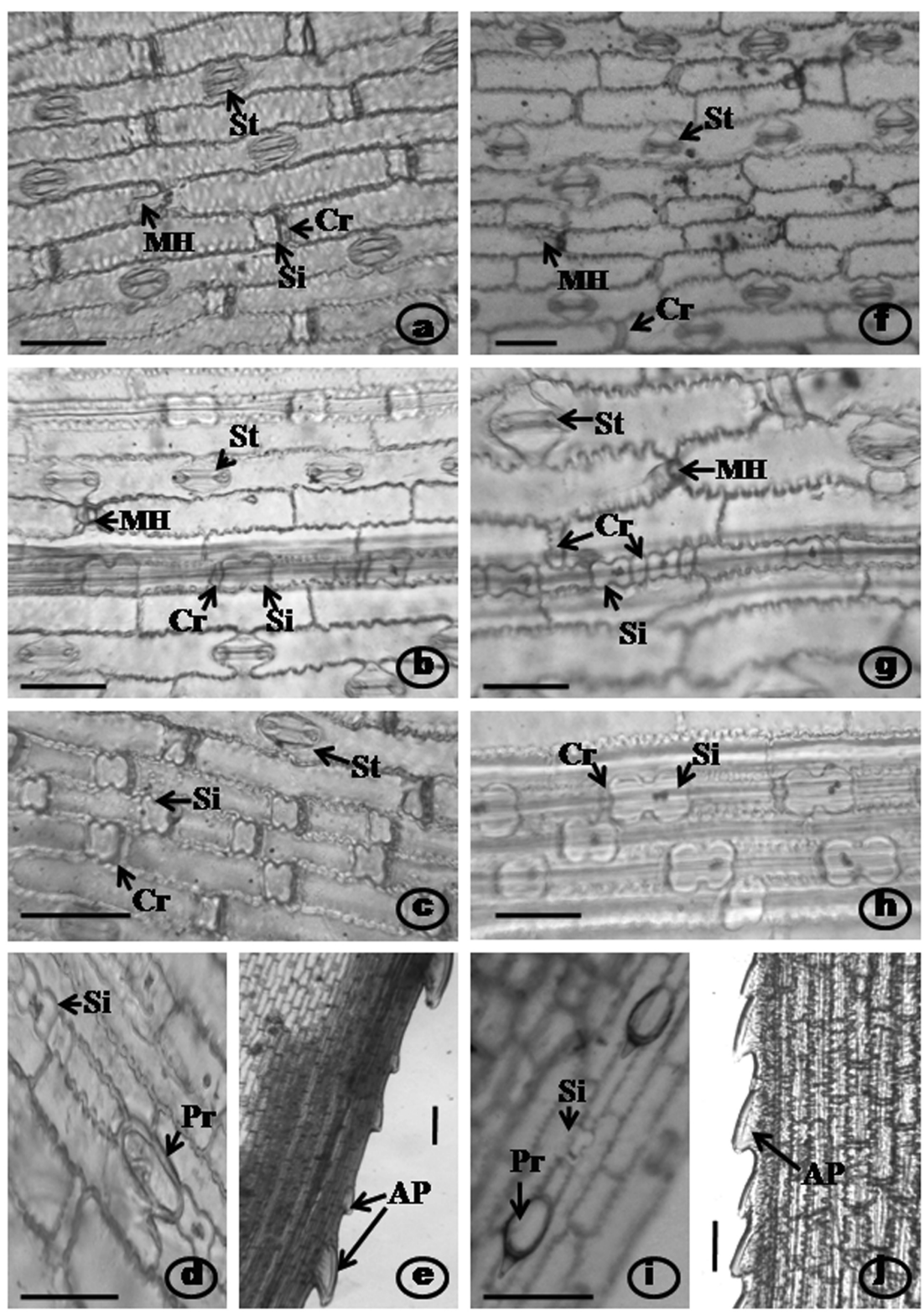

Fig. 1._a. Abaxial epidermis of C. lacryma-jobi showing cross shaped silica cells paired with Cork cells, Microhair and stomata. b. Adaxial epidermis of C. lacryma-jobi showing cross shaped silica cells paired with Cork cells, base of Microhair and stomata. c. Costal region of abaxial epidermis of C. lacryma-jobi showing cross shaped silica cells paired with Cork cells and stomata. d. Adaxial Prickle hairs of C. lacryma-jobi showing silica cells and Prickle hairs with blunt apex.

e. Angular hairs on the leaf margin of C. lacryma-jobi showing discontinuous row of smaller and larger sized Angular Prickles.

f. Abaxial epidermis of C. aquatica showing Cork cells, Microhair and stomata.

g. Adaxial epidermis of $C$. aquatica showing dumbbell shaped silica cells paired with Cork cells, Microhair and stomata.

h. Costal region of abaxial epidermis of $C$. aquatica showing three rows of dumbbell shaped silica cells paired with Cork cells. i. Adaxial Prickle hairs of C. aquatica showing silica cells and Prickle hairs with sharp pointed apex.

j. Angular hairs on the leaf margin of C. aquatica showing continuous row of Angular Prickles of equal sizes.

(Bar $=50 \mu$; Figure legend. St: Stomata, MH: Microhair, Si: Silica cell, Cr: Cork cell, Pr: Prickle hair, AP: Angular Prickle). 
40

between the veins on the adaxial surface while, the long cells recorded in C. aquatica were 10-16 rowed and 8-12 rowed between the veins on the abaxial and adaxial epidermis respectively. Microhairs were seen sparsely distributed in both the epidermis of both the species of Coix, longer in C. aquatica $(70 \mu)$ and C. lacryma-jobi $(50 \mu)$ (Fig. 1 a and g). Formerly, Amarsinghe and Watson (1990) have already described the significance of microhair morphology in Eragrostis for infrageneric classification.

The characters of diagnostic importance in the identification of $C$. aquatica are long and sharply pointed prickle hairs present in adaxial epidermis only (Fig. 1 i) while with blunt apex in C. lacryma-jobi (Fig. $1 \mathrm{~d}$ ). In addition to prickle hairs, angular prickles are recorded on the margin of the leaves with significant variation in size and arrangement (Fig. 1 e and $\mathbf{j}$ ). The diagnostic characters for C. lacryma-jobi are the cross shaped silica cells over and between the veins in the abaxial epidermis which were absent in $C$. aquatica. Adaxial epidermis of C. lacryma$j o b i$ and both the epidermis of $C$. aquatica shows presence of dumbbell shaped silica cells over the veins only. These micromorphological characters clearly separate the two species of Coix. Krishanan et al. (2004) has already classified the south Indian grasses on the basis of phytoliths, i.e. silica bodies.

Moreover, veins are of 3 rowed of silica cells in abaxial epidermis (Fig. $1 \mathrm{c}$ and $\mathrm{h}$ ) while single rowed in adaxial epidermis of both the species. In addition, abundance of stomata and silica cells was observed on the abaxial epidermis of the C. lacryma-jobi (Fig. 1 a) than the C. aquatica (Fig. $1 \mathrm{f})$, while stomata were found sparsely distributed on the adaxial epidermis of both species (Fig. $1 \mathrm{~b}$ and g). But the arrangement of the stomata still showed some differences in that, the stomata present were 10-12 banded between the veins on the abaxial and 1-4 banded between the veins on the adaxial epidermis of C. lacryma-jobi. In C. aquat$i c a$, the stomata were seen 3-4 banded between the veins on the abaxial and 4-6 banded between the veins on the adaxial epidermis. Due to the close relationships between the two species, some characters such as stomata, shapes of the subsidiary cells, long cells, the microhairs and cork cells seen among the accessions of the two species studied could not adequately distinguish between $C$. aquatica and C. lacryma-jobi. Although the width of stomata showed slight differences, the length of stomata found in the two species were almost the same. In addition, the average widths of long cells seen in the adaxial epidermis of the two species were more or less the same. The present study reveals that some of the characters, which were present in the two species, may be typical of the genus despite the many micromorphological variations between them.

\section{Conclusions}

The characters of diagnostic importance in the identification of $C$. aquatica are long and sharply pointed prickle hairs, angular prickles on the margin of the leaves and absence of cross shaped silica cells. While, presence of prickle hairs with blunt apex and cross shaped silica cells are the characteristic features of C. lacryma-jobi. These micromorphological characters clearly separate the two species of Coix.

\section{References}

Acedo, C. and F.Llamas (2001). Variation of micromorphological characters of lemma and palea in the genus Bromus (Poaceae). Ann. Bot. Fennici. 38, 1-14.

Amarasinghe, V.and L. Watson (1990). Taxonomic Singnificance of Microhair Morphology in the Genus Eragrostis Beauv. (Poaceae). Taxon. 39, 59-65.

Clayton, W. D. and S. A. Renvoize (1999). Genera Graminum: Grasses of the world. Kew Bulletin additional series XIII. Royal Botanical Gardens. Kew. London. pp.651.

GPWG (Grass Phylogeny Working Group) (2001). Phylogeny and subfamilial classification of the grasses (Poaceae). Ann. Misso. Bot. Gar. 88, 373-457.

Hilu, K. W. and J. L. Randall (1984). Convenient Method for Studying Grass Leaf epidermis. Taxon. 33, 413-415.

Jain, S. K. and D. Benerjee (1974). Preliminary observations on the ethanobotany of the genus Coix. Eco. Bot. 28, 38-42.

Krishnan, S., N. P. Samson, P. Ravichandran, D. Narasimhan and P. Dayanandan (2000). Phytoliths of Indian grasses and their potential use in identification. Bot. J. Linn. Soc. 132, 241-252.

Metcalfe, C. R. (1960). Anatomy of the Monocotyledons I-Gramineae. Oxford University Press. London. pp.1-711.

Ogundipe, O. T. and O. A. Olatunji (1991). Vegetative anatomy of Brachiaria obtussiflora (Hochst ex. A. Rich.) Stapf and Brachiaria callopus (pilg.) Stapf (Poeaceae). Feddes Reportorium. 102, 159-166.

Renvoize, S. A. (1982). A survey of leaf blade anatomy in grasses. I. Andropogoneae, Kew Bull. 37, 315-321.

Srivastava, A. K. (1978). Study of leaf epidermis in the genus Digitaria Rich (Gramineae). J. Ind. Bot. Soc. 37, 155-160.

Stace, C. A. (1984). The taxonomic importance of the leaf surface. In V. H. Herwood, D. M. Moore (eds.), Current Concepts in Plant Taxonomy Systematic Association Special. vol. 25, Academic Press. London and Orlando.

Whang, S., S. K. Kim and W. M. Hess (1998). Variation of silica bodies in leaf epidermal long cells within and among seventeen species of Oryza (Poaceae). Ame. J. Bot. 85, 461466.

Watson, L. and M. J. Dallwitz (1992). Onwards. The grass genera of the world: descriptions, illustrations, identification, and information retrieval; including synonyms, morphology, anatomy, physiology, phytochemistry, cytology, classification, pathogens, world and local distribution, and references. http://delta-intkey.com/grass/www/coix.htm 